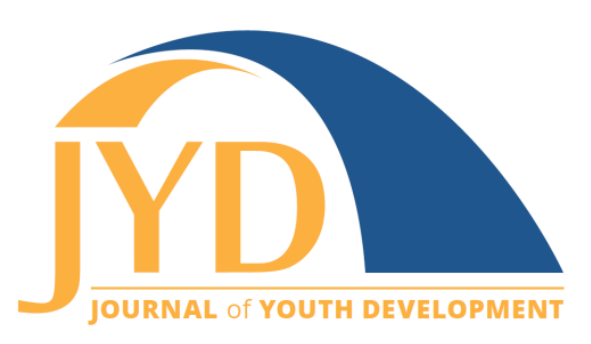

http://jyd. pitt. edu/ | Vol. 14 Issue 4 DOI 10.5195/jyd.2019.791 | ISSN 2325-4017 (online)

\title{
Assessing Risk Management Knowledge of Florida 4-H Professionals Relating to Shooting Sports
}

\author{
Matt Benge \\ University of Florida \\ mattbenge@ufl.edu \\ Genevieve Mendoza \\ University of Florida \\ mendozag@ufl.edu \\ Glenn D. Israel \\ University of Florida \\ gdisrael@ufl.edu
}

\begin{abstract}
Florida is one of 48 states that offer shooting sports as part of their 4-H program. While young people participating in 4-H shooting sports gain valuable life skills, what has remained unclear are the skills needed by county 4-H agents to manage the risks associated with offering the program. $A$ needs assessment was conducted to identify Florida 4-H agents' perceived level of competency in program procedural standards and program leadership accountability as it relates to managing a county 4-H shooting sports program. The results of the study demonstrated that Florida 4-H agents recognized the value of having program procedural standards and program leadership accountability but lacked the knowledge and skills to implement them as part of managing the risks associated with providing a 4-H shooting sports program. In addition, specific needs identified by respondents to better prepare county 4- $H$ agents to manage the program were training, equipment, curriculum, and better communication from the Florida 4-H state office. Florida 4-H should provide prioritized training, resources, and curriculum development to better prepare county 4-H agents with managing their county 4-H shooting sports programs.
\end{abstract}

Key words: risk management, competencies, shooting sports, 4-H

(cc) EY New articles in this journal are licensed under a Creative Commons Attribution 4.0 License. This journal is published by the University Library System, University of Pittsburgh and is cosponsored by the University of Pittsburgh Press. The Journal of Youth Development is the official peer-reviewed publication of the National Association of Extension 4-H Agents and the National AfterSchool Association. 


\section{Introduction}

The 4-H program is the largest youth-serving organization in the United States, with nearly six million youth participants nationwide, and is delivered through the land-grant university system (National 4-H Council, 2018). Youth members can participate in a multitude of projects, including environmental education, leadership, and animal sciences, as well as in diverse settings such as after-school programs, community clubs, and summer camp activities. The 4-H program can best be described as a youth development organization which "empowers young people with the skills to lead for a lifetime" through hands-on, learn-by-doing opportunities delivered through a network of over 100 public universities (National 4-H Council, 2018, para. 2).

The 4-H program in the state of Florida reaches approximately 200,000 youth who participate in over 275,000 projects, annually (Florida $4-H, 2018$ ). In 2017, 2,500 youth participated in the Florida 4-H shooting sports program, which is classified under environmental education. The 4- $\mathrm{H}$ shooting sports program is active in 48 states and is a competitive and recreational activity with a focus on marksmanship, firearm safety, responsibility, and decision-making (Culen \& Mitchell, 2017; Sabo \& Hamilton, 1997). In a study conducted by the Pew Research Center (2017), $95 \%$ of gun owners and $89 \%$ of non-gun owners agreed that talking to their children about gun safety was an essential responsibility of gun owners. The study also found that $59 \%$ of gun owners and $79 \%$ non-gun owners agreed that taking gun safety courses was another essential responsibility of gun owners. Within the context of offering a shooting sports program, there is a heightened awareness of risk since firearms have the potential to cause permanent and catastrophic harm to physical and emotional well-being, as well as damage to physical property, increased legal and financial liability and challenges with volunteer management (Goodwin, White, \& Sandlin, 2019; White \& Williver, 2014).

Herman (2011) defines risk management as the discipline for dealing with uncertainly. Risk is inherent in everyday life, projects, and activities, yet organizations thwart risk by implementing management strategies to decrease potential issues and threats so that their service to the community can be fulfilled. Organizations typically manage risks with an operational lens, focusing on the organization's people, processes, systems, and external forces, and using techniques that include training and development, inventorying assets, communication, and establishing rules and requirements (Herman, 2011). Goodwin et al. (2019) found that "4-H Shooting Sports is one of the safest educational, recreational, and competitive activities in which youths can be involved" (para 10), signifying that though there is potential risk in 


\section{Assessing Risk Management in Shooting Sports}

participating in a 4-H shooting sports program, that same potential risk is much lower than many other youth extracurricular activities. Even so, White and Smith (2014) explain that 4-H educators have a responsibility to manage risk with a shooting sports program.

The adoption of the train-the-trainer approach for certification of qualified instructors "is an effective method to increase program capacity and outreach efforts" and minimizes risk through capacity building (Fields, Brown, Piechocinski, \& Wells, 2012, para 5). In addition to the trainthe-trainer approach, a series of minimum standards and best management practices were established and periodically reviewed by the national 4-H shooting sports committee, which was comprised of 10 to 15 individuals with at least two representatives from each region of the United States (C. Arnold, personal communication, May 29, 2018). According to the national 4-H shooting sports committee, all active state 4-H shooting sports programs were "advised to adopt and adhere to these standards at the state and county level" (National 4-H Shooting Sports Committee, 2016, para 1). All of these measures were implemented to manage the risks associated with offering a shooting sports program and to promote the 4-H essential elements.

A great deal of emphasis by the National 4-H Shooting Sports committee has been placed on establishing and maintaining a quality train-the-trainer approach to manage risk at the level of the shooting sports instructors; however, little attention has been placed on assessing county 4$\mathrm{H}$ agents' adoption of national program procedural standards and program leadership accountability principles at the local level. Furthermore, the focus of research pertaining to positive youth development and risk management emphasized strategies directed towards youth and volunteers to engage in sound, emotionally and physically safe, educational programs (Fultz, 1997; Miller \& Schmiesing, 2008). Witkin and Altschuld (1995) explain that assessing the needs of an organization is imperative to providing quality information and perceptions to guide the making of policy and program decisions. No known research has been published in the Extension literature assessing the needs of county 4-H agents to manage the risks associated with planning and conducting educational programs for youth interested in shooting sports.

The Florida 4-H shooting sports program has a unique opportunity to provide young people and their families educational experiences that support safe, responsible handling of shooting sports equipment. Though the national shooting sports committee has focused on programmatic uniformity for volunteer instructor trainings and establishing standards and expectations for competitive matches (Culen, personal communication, 2018), little attention has been placed on other risk management issues of the county 4-H shooting sports program in Florida. Assessing 


\section{Assessing Risk Management in Shooting Sports}

program standards, policies, and procedures under the auspices of program procedural standards and program leadership accountability reveals the appropriate requirements for mitigating these potential risks and for providing a shooting sports program that matches the developmental needs of its youth participants (Fultz, 1997; Landrigan, 1999).

\section{Purpose and Objectives}

The purpose of this study was to determine the needs of Florida county 4-H agents for managing the localized responsibilities and risks associated with providing a shooting sports program. The following objectives were developed to guide the study:

1. Describe the current scope of the Florida 4-H Shooting Sports program.

2. Identify Florida county 4-H agents' level of competency of program procedural standards and accountability for managing a shooting sports program.

3. Determine the needs of Florida county 4-H agents for specific in-service and program resources pertaining to safely managing a shooting sports program.

For the purposes of this study, the following definitions are provided:

1. Program leadership accountability - describes the decision-making functions of the program for determining program policies and procedures.

2. Program procedural standards - describes the operational functions of the program for carrying out the program policies and procedures.

3. Risk management - The discipline for dealing with uncertainly.

\section{Methods}

The researchers used a web-based questionnaire to measure the knowledge gap of program procedural standards and program leadership accountability for managing a county shooting sports program. The tailored design method for Internet questionnaires (Dillman, Smyth, \& Christian, 2014) was used to collect the data. Recommended best practices were used for webbased data collection such as using multiple short, concise messages for conducting each contact (Dillman et al., 2014; Israel, 2013). Based on best practices of the tailored designed method, 3 weeks were needed for data collection.

The study population included all county 4-H agents employed by the state of Florida. A list of current county 4-H agents ( $n=71$ ) was obtained from the Florida Extension Business Services office. Due to the small population size of county $4-\mathrm{H}$ agents for this study, a census was 


\section{Assessing Risk Management in Shooting Sports}

conducted in lieu of a random sample. A census is suitable when a complete count of the population can be conducted, which eliminates sampling error (Dillman et al., 2014).

The researchers developed an instrument to assess the competencies needed to manage the risks associated with providing a shooting sports program, as no previous research or instrument was found in the literature. The instrument included 22 questions or statements, six of which referred to demographic and program data and three open-ended questions to solicit more detailed descriptions from respondents. Ten statements were included to measure the respondents' level of competency of program procedural standards and program leadership accountability principles. Program procedural standards were measured to identify needs pertaining to the operational functions of the shooting sports program within a county whereas the program leadership accountability construct was measured to determine the needs pertaining to program leadership and accountability principles. The items were based on best practices and program standards established by the National 4-H shooting sports committee (National 4-H Shooting Sports Committee, 2016) and resources provided during the Florida level-1 shooting sports instructor certification workshop.

To ensure reliability and validity were maximized, the instrument was reviewed by an expert panel (Shadish, Cook, \& Campbell, 2002) of five members: the Florida shooting sports coordinator who is also an Extension specialist, two state evaluation specialists, and two members of the Florida shooting sports committee. In addition, two members of the expert panel are current instructors of the Florida level-1 shooting sports instructor certification workshops. Following the expert panel review, some statements were modified, and additional statements were added to increase the likelihood of obtaining valid and reliable results. The contributions from the expert panel indicated both constructs were appropriate and encompassed the overarching concept of managing risks associated with a shooting sports program.

Data were collected through Qualtrics, a web-based research software used to collect and analyze data. The Tailored Design Method (Dillman et al., 2014) was used to increase response rates. A pre-notice, an invitation notice, and three follow-up notices were sent by e-mail to increase response rates. Invitations containing a link to the online questionnaire were e-mailed to the population. Three e-mails bounced back due to incorrect e-mail addresses. The incorrect e-mail addresses were corrected and included in subsequent correspondences. Thirty-seven questionnaires were completed for an overall response rate of $52 \%$. Nonresponse was addressed by comparing early to late respondents. No significant differences existed between 


\section{Assessing Risk Management in Shooting Sports}

early and late respondents. Therefore, the results can be generalized to the entire population of Florida 4-H Extension agents (Lindner, Murphy, \& Briers, 2001).

Once the collection of data was complete, descriptive statistics were analyzed for 18 statements. Three open-ended questions were also included for which researchers used a simple thematic analysis to reduce data from open-ended questions into identifiable, recurrent themes (Lincoln \& Guba, 1985; Merriam, 1998). Direct quotes from respondents were used to contribute to the descriptive findings of the study (Merriam, 2009). Bias from the researchers can affect the way qualitative data is analyzed and interpreted (Merriam, 2009). For this assessment, one of the researchers is a county faculty member with experience in 4- $\mathrm{H}$ and Extension and also conducts programming in shooting sports. The other researchers are state Extension specialists with expertise in 4-H and program development and evaluation; one has served as a 4-H Extension agent for 7 years. Limitations to the study include: (a) receptiveness of the targeted audience to be surveyed, (b) potential researcher bias of presumed outcomes, (c) measurement error in the research instrument, and (d) non-response error.

\section{Findings}

\section{Objective 1 Results}

Objective 1 was to describe the scope of the Florida 4-H Shooting Sports program. All five Florida Extension districts were represented among the 37 respondents. Table 1 provides a brief description of the demographic characteristics of respondents.

The five respondents' programs that did not provide a shooting sports program indicated they would consider offering the program in the future. The common theme among respondents for reasons why the program presently did not exist in their county was access to training for volunteers. One respondent indicated they "lost clubs due to lack of responsiveness to training needs." When respondents $(n=36)$ were asked what resources were needed to support a county shooting sports program, the recurring theme was a need for more frequent level 1 shooting sports instructor certification trainings.

Shooting sport disciplines offered in the 32 county 4-H shooting sports programs varied widely. Most programs ( $n=30$ ) offered archery, but muzzleloading and hunting and wildlife were each offered by only four programs. The most frequent delivery modes for the shooting sports programs were community clubs $(n=29)$ and camps $(n=12)$. Management responsibilities for 
Journal of Youth Development | http://jyd.pitt.edu/ | Vol. 14 Issue 4 DOI 10.5195/jyd.2019.791 Assessing Risk Management in Shooting Sports

clubs were shared among 4-H agents, staff, and volunteers. Table 2 provides a description of the shooting sports disciplines offered, program frequency of delivery mode, and management of the program for the county 4-H program.

Table 1. Demographic Characteristics of Respondents

\begin{tabular}{|c|c|c|}
\hline & $f$ & $\%$ \\
\hline \multicolumn{3}{|l|}{ Years working in Extension } \\
\hline $0-5$ & 15 & $42 \%$ \\
\hline $6-10$ & 10 & $28 \%$ \\
\hline $11-15$ & 3 & $8 \%$ \\
\hline 16 or more & 9 & $22 \%$ \\
\hline \multicolumn{3}{|l|}{ Extension district } \\
\hline Northwest & 6 & $16 \%$ \\
\hline Northeast & 11 & $31 \%$ \\
\hline Central & 8 & $22 \%$ \\
\hline Southwest & 8 & $22 \%$ \\
\hline Southeast & 4 & $11 \%$ \\
\hline \multicolumn{3}{|l|}{ Offer a shooting sports program } \\
\hline Yes & 32 & $80 \%$ \\
\hline No & 5 & $14 \%$ \\
\hline
\end{tabular}

Table 2. Description of County Shooting Sports Programs $(n=32)$

\begin{tabular}{|l|c|c|}
\hline & $f$ & $\%$ \\
\hline Shooting sports disciplines & & \\
\hline Archery & 30 & $94 \%$ \\
\hline Rifle & 19 & $59 \%$ \\
\hline Shotgun & 17 & $53 \%$ \\
\hline Muzzleloading & 4 & $13 \%$ \\
\hline Hunting \& wildlife & 4 & $13 \%$ \\
\hline
\end{tabular}


Table 2 (continued)

\begin{tabular}{|c|c|c|}
\hline & $f$ & $\%$ \\
\hline Program delivery mode (all shooting sports disciplines) & & \\
\hline Community clubs & 29 & $91 \%$ \\
\hline Residential and day camp & 12 & $38 \%$ \\
\hline After-school and in-school clubs & 6 & $19 \%$ \\
\hline School enrichment & 1 & $3 \%$ \\
\hline Management of county shooting sports program & & \\
\hline 4-H agent & 20 & $63 \%$ \\
\hline Volunteers & 13 & $41 \%$ \\
\hline 4-H staff & 5 & $16 \%$ \\
\hline
\end{tabular}

\section{Objective 2 Results}

Objective 2 was to identify county 4-H agents' level of competency of program procedural standards and program leadership accountability for managing a county shooting sports program. Table 3 shows the rate of correct responses out of the number who responded to each question.

Table 3. Assessment of Respondents' Knowledge of Program Procedural Standards

\begin{tabular}{|c|c|c|}
\hline $\begin{array}{l}\text { Program procedural standards question } \\
\text { Correct answer }\end{array}$ & $\begin{array}{l}\text { Rate of } \\
\text { correct } \\
\text { responses }\end{array}$ & $\begin{array}{l}\% \\
\text { correct }\end{array}$ \\
\hline $\begin{array}{l}\text { 1. How often should shooting sports equipment be inspected? } \\
\text { Each time equipment is used }\end{array}$ & $27 / 31$ & $87 \%$ \\
\hline $\begin{array}{l}\text { 2. How often should range rosters be used during shooting sports activities? } \\
\text { Every time youth shoot on the range }\end{array}$ & $22 / 33$ & $67 \%$ \\
\hline $\begin{array}{l}\text { 3. What is the minimum age for a } 4-\mathrm{H} \text { youth to participate in the shotgun discipline? } \\
\qquad 10\end{array}$ & $10 / 32$ & $31 \%$ \\
\hline $\begin{array}{l}\text { 4. Please select which items are included on the firearm equipment inventory form } \\
\text { provided by Florida 4-H Shooting Sports. } \\
\text { Date acquired, methods of securing equipment, model, and caliber or gauge }\end{array}$ & $8 / 29$ & $28 \%$ \\
\hline $\begin{array}{l}\text { 5. Which shooting sports discipline has an adult to youth ratio of } 1: 5 \text { ? } \\
\text { Shotgun }\end{array}$ & $8 / 32$ & $25 \%$ \\
\hline
\end{tabular}


Assessing Risk Management in Shooting Sports

Table 4 displays respondents' knowledge of program leadership accountability questions. All participants knew to maintain an accurate and up-to-date inventory of shooting sports equipment, and 97\% ( $n=32$ ) knew equipment should be checked out to youth during practices or meetings. Responses to questions about other leadership accountability topics indicated weaker knowledge of those areas.

Table 4. Assessment of Respondents' Knowledge of Program Leadership Accountability

\begin{tabular}{|c|c|c|}
\hline $\begin{array}{l}\text { Program leadership accountability questions } \\
\text { Correct Answer }\end{array}$ & $\begin{array}{l}\text { Rate of } \\
\text { correct } \\
\text { responses }\end{array}$ & $\%$ correct \\
\hline $\begin{array}{l}\text { The county 4-H Shooting Sports program does not need to maintain an accurate and } \\
\text { up-to-date inventory of shooting sports equipment. } \\
\text { False }\end{array}$ & $32 / 32$ & $100 \%$ \\
\hline $\begin{array}{l}\text { Shooting sports equipment should only be checked out to youth members during } \\
\text { shooting sports practices or meetings. } \\
\text { True }\end{array}$ & $32 / 33$ & $97 \%$ \\
\hline $\begin{array}{l}\text { The Florida 4-H Shooting Sports policies on storage and transportation of ammunition } \\
\text { are based on which entity? } \\
\text { Florida Law }\end{array}$ & $16 / 32$ & $50 \%$ \\
\hline $\begin{array}{l}\text { Liability insurance coverage requirements for shooting sports activities is treated } \\
\text { similarly to liability insurance coverage requirements for equestrian activities. } \\
\text { False }\end{array}$ & $13 / 33$ & $39 \%$ \\
\hline $\begin{array}{l}\text { Each county's shooting sports risk management plan (RMP) should be reviewed and } \\
\text { submitted to the State 4-H Shooting Sports Coordinator... } \\
\text { At least once every year }\end{array}$ & $12 / 31$ & $39 \%$ \\
\hline
\end{tabular}

The average score for each construct is displayed in Table 5.

Table 5. Average Score for Program Procedural Standards and Program Leadership Accountability.

\begin{tabular}{|l|l|}
\hline Risk Management Construct & Average Score \% \\
\hline Program Procedural Standards & $48 \%$ \\
\hline Program Leadership Accountability & $65 \%$ \\
\hline
\end{tabular}




\section{Objective 3 Results}

The third objective was to determine the needs of county 4-H agents for specific in-service and program resources pertaining to Florida 4-H shooting sports program standards and accountability. An open-ended question was included for respondents to indicate what resources were needed to support the 4-H agent's role in managing the county 4-H shooting sports program (See Table 6). The most common resources identified by respondents was more training and development opportunities, followed by policies and procedures, and support from the state $4-\mathrm{H}$ office. The least common resources identified by respondents were equipment and locations. Specific training and development topics included how to start a shooting sports program (Respondent 1), online training opportunities (Respondent 8), trainings on the pros and cons as to whether an agent should keep a shooting sports program (Respondent 12), and overall shooting sports program management (Respondent 17). Respondent 15 stated,

As a newcomer, I do not fully understand all that is required to maintain the program. I do not know the rules on proper storage, inventory of equipment, and range requirements. I believe in order to support an agent with a full-fledged shooting sports program, they need some sort of checklist to assist them with the program and also need direction or guidance from other agents who have successful shooting sports programs.

Table 6. Resources Needed to Manage a County 4-H Shooting Sports Program.

\begin{tabular}{|l|c|}
\hline Type of Resource & $\boldsymbol{f}$ \\
\hline Training and development & 17 \\
\hline Policies and procedures & 9 \\
\hline Support from state 4-H office & 6 \\
\hline Information materials & 4 \\
\hline Curriculum & 3 \\
\hline Funding and grants & 2 \\
\hline Updated volunteer records & 2 \\
\hline Equipment & 1 \\
\hline Locations & 1 \\
\hline
\end{tabular}




\section{Assessing Risk Management in Shooting Sports}

\section{Discussion and Implications}

The purpose of this study was to determine the needs of Florida county 4-H agents for managing the localized responsibilities and risks associated with providing a shooting sports program. Previous research and needs assessments concerning county agents could not be found within the Extension literature, signifying a lack of investment in assessing competencies and training in both practice and research. 4-H youth development professionals are the managers of the county 4- $\mathrm{H}$ program and as such, are the frontline agents for supervising and enforcing risk management policies and procedures; they need to be adequately trained and prepared to do so (White \& Smith, 2014).

A majority of Florida county 4-H programs offer a shooting sports program with an archery discipline and in a community club setting. The availability of various shooting sports disciplines, coupled with different delivery modes, provides the opportunity for the county 4-H programs in Florida to reach unique audiences in unique settings within a community. In addition, the person responsible for managing the shooting sports program must be able to do so competently (Herman, 2011). This study found that sixty-three percent of county 4-H shooting sports programs were managed by $4-\mathrm{H}$ agents, and forty-one percent were managed by 4-H volunteers. This suggests that 4-H shooting sports programs in Florida are not managed by similar personnel and, therefore, need different trainings for those managing the program, along with different policies and procedures that are tailored for both the specific shooting sports discipline and mode of delivery within the community.

Respondents were asked to demonstrate their knowledge and competency of Florida 4-H shooting sports program procedural standards and program leadership accountability; average scores were $48 \%$ and $65 \%$, respectively. Herman (2011) asserted that employees should be knowledgeable of policies and procedures, and Fultz (1997) and Landrigan (1999) agreed that assessing program standards, policies, and procedures helps to mitigate potential risks. Results from this study indicate that Florida 4-H Extension agents are not knowledgeable enough to effectively manage their county $4-\mathrm{H}$ shooting sports programs. Length of employment may be a factor: $42 \%$ of respondents have worked in $4-\mathrm{H}$ for 5 years or less, which may not be enough time to develop the skills necessary to safely manage a shooting sports program. Furthermore, only three of the 10 questions had a correct response rate above $80 \%$, indicating the competencies needed to safely manage a county shooting sports program were lacking in county 4-H agents in Florida regardless of how many years they worked in Extension. One respondent stated, "Some agents inherit programs, others start them with the idea of [positive 


\section{Assessing Risk Management in Shooting Sports}

youth development] and not the ins and outs of a [shooting sports] program," signifying that ongoing training and professional development within Extension needs to be made available.

Florida 4-H Extension agents responding to this needs assessment reported training and development as the highest need to manage a county 4-H shooting sports program, followed by policies and procedures, and support from the Florida 4-H state office. Florida 4-H youth professionals desire structure, training, and development to further enhance their shooting sports programs, as well as support and communication from the Florida 4-H state office regarding the shooting sports program. Additionally, training topics differentiated amongst shooting sports program as a whole versus discipline-specific training is needed, as well as for new versus experienced agents. An overall need indicated by respondents was availability of resources such as training, availability of state 4-H shooting sports personnel, and availability of policies and procedures, indicating an overarching needs for the Florida 4-H program to provide and make readily available resources and materials to county $4-\mathrm{H}$ agents.

\section{Recommendations}

Based on the finding of this study, the researchers provide recommendations and guidance for both practitioners and research. Herman (2011) suggests the development of a risk management committee made up of both Florida 4-H Extension agents and volunteers who have knowledge of and experience with the shooting sports program to prioritize and guide the needs described in this study. The committee should be made up of both experienced and new Florida 4-H extension agents and volunteers to ensure a variety of input is available. A second recommendation for Florida practitioners is to make resources such as documents, forms, state 4-H personnel, policies, and curriculum accessible to $4-\mathrm{H}$ agents and volunteers who lead the county 4-H shooting sports program. Respondents in this study indicated clear communication between the state $4-\mathrm{H}$ office and county $4-\mathrm{H}$ agents is critical. Florida $4-\mathrm{H}$ should create a readily accessible repository where resources and materials can be accessed and shared. Additionally, other states should assess their available resources for shooting sports and other project areas to ensure the resources are accurate and up-to-date.

A third recommendation for practitioners, both for Florida and other state 4-H programs, is to provide adequate and up-to-date training and development for employees as Herman (2011) suggests to effectively minimize risk and increase understanding of policies and protocols necessary to manage a county $4-\mathrm{H}$ shooting sports program. Online orientation materials and resources should be created and added to the repository for new 4-H extension agents and 


\section{Assessing Risk Management in Shooting Sports}

volunteers who will be managing the shooting sports programs. Some examples of information in this training are policies and procedures, how to manage a shooting sports program, certification requirements, and best management practices. State 4-H programs can look to the National 4-H Shooting Sports Committee for resources and available training that can be used or modified to fit their specific state. In addition, we recommend that a retraining program be created for those who currently manage a county 4-H shooting sports program in Florida to stay up to date with new policies or information.

A research recommendation that goes beyond the breadth of this study is for Florida 4- $\mathrm{H}$ and other state 4-H programs, to continually evaluate and assess the quality of their programs, trainings, and resources to effectively manage the 4-H program. Fewer than five studies could be found relating to risk management during the literature review for this study. Furthermore, there is an overall lack of research and practice of assessing 4-H programmatic needs throughout 4-H nationwide. State 4-H programs should spend resources to assess risks associated with other 4-H programs such as livestock, horse, and camp. A second research recommendation is to conduct a national study in partnership with the National 4-H Shooting Sports Committee to evaluate the needs of county 4-H agents and volunteers within the state shooting sports programs to determine if the current available trainings, both at the national and state levels, are sufficient for managing risk. Evaluation of such trainings could include local county $4-\mathrm{H}$ volunteer trainings and state level volunteer trainings, as well as the national certification process $4-\mathrm{H}$ shooting sports instructors.

\section{References}

Culen, J., \& Mitchell, R. (2017). Perceptions of adult and youth participants regarding positive youth development life skills, family-community connections and safety knowledge in the Florida 4-H shooting sports program. Manuscript submitted for publication.

Dillman, D. A., Smyth, J. D., \& Christian, L. M. (2014). Internet, phone, mail, and mixed-mode surveys: The tailored design method ( $4^{\text {th }}$ ed.). Hoboken, $\mathrm{NJ}$ : John Wiley \& Sons.

Fields, N., Brown, M., Piechocinski, A., \& Wells, K. (2012). A statewide train-the-trainer model for effective entrepreneurship and workforce readiness programming. Journal of Extension, 50(5). Retrieved from https://www.joe.org/joe/2012october/tt9.php

Florida 4-H. (2017). Florida 4-H facts \& impacts. University of Florida, Gainesville, Florida. Retrieved from http://florida4h.org/about/impact/

Fultz, R. A. (1997). 4-H shooting sports...a risky business! Proceedings from a National 4-H Instructor Training. Retrieved from http://w3.4-hshootingsports.org/risk_mgmt/Risky\%20Business.pdf 
Goodwin, J., White, D. J., \& Sandlin, M. R. (2019). 4-H members and firearms: The case for 4-H shooting sports. Journal of Extension, $5 \lambda(1)$. Retrieved from https://joe.org/joe/2019february/comm2.php Herman, M. L. (2011). Ready . . or not: A risk management guide for nonprofit executives ( $2^{\text {nd }}$ ed.). Leesburg, VA: Nonprofit Risk Management Center.

Israel, G. D. (2013). Using mixed-mode contacts in client surveys: Getting more bang for your buck. Journal of Extension, 51(3). Retrieved from http://www.joe.org/joe/2013june/a1.php

Landrigan, P. J. (1999). Risk assessment for children and other sensitive populations. Annals of the New York Academy of Sciences, 895(1), 1-9. doi:10.1111/j.1749-6632.1999.tb08073.x

Lincoln, Y. S., \& Guba, E. G. (1985). Naturalistic inquiry. Thousand Oaks, CA: Sage.

Lindner, J. R., Murphy, T. H., \& Briers, G. E. (2001). Handling nonresponse in social science research. Journal of Agricultural Education, 42(4), 43-53. doi:10.5032/jae.2001.04043

Merriam, S. B. (1998). Qualitative research and case study applications in education. San Francisco, CA: Jossey-Bass.

Merriam, S. B. (2009). Qualitative research: $A$ guide to design and implementation ( $2^{\text {nd }}$ ed.). San Francisco, CA: Jossey-Bass.

Miller, L., \& Schmiesing, R. (2008). Youth program risk management: A case study of the 4-H PetPals program. Journal of Extension, 46(5). Retrieved from https://www.joe.org/joe/2008october/a5.php

National 4-H Council (2018). 4-H history. Retrieved from https://4-h.org/about/history/

National 4-H Shooting Sports Committee. (2018). Minimum standards \& best management practices of a 4-H shooting sports program as established by the national 4-H shooting sports committee. Retrieved from http://w3.4-hshootingsports.org/instructor_resources/National\%204H\%20SS\%20 Minimum\%20Standards\%20Best\%20Practices\%201-19.pdf

Sabo, K. E., \& Hamilton, W. V. (1997). 4-H shooting sports hits the mark with youth-at-risk. Journal of Extension, 35(5). Retrieved from https://www.joe.org/joe/1997october/a3.php

Shadish, W. R., Cook, T. D., \& Campbell, D. T. (2002). Experimental and quasi-experimental designs for generalized causal inference. Belmont, CA: Wadsworth.

White, D. J., \& Smith, J. D. (2014). Acquisition, custody, and storage of firearms used in 4-H shooting sports programs. Journal of Extension, 52(5). Retrieved from https://www.joe.org/joe/2014october/tt10.php

White, D. J., \& Willver, S. T. (2014). Possession, transportation, and use of firearms by older youth in 4-H shooting sports programs. Journal of Extension, 52(3). Retrieved from https://joe.org/joe/2014june/tt9.php

Witkin, B. R., \& Altschuld, J. W. (1995). Planning and conducting needs assessments: A practical guide. Thousand Oaks, CA: Sage. 